\title{
Bioaugmentation of ensiled Caragana korshinskii Kom. with a rapid start-up Pediococcus acidilactici and cellulases: Fermentation profiles, bacterial community composition and enzymatic saccharification
}

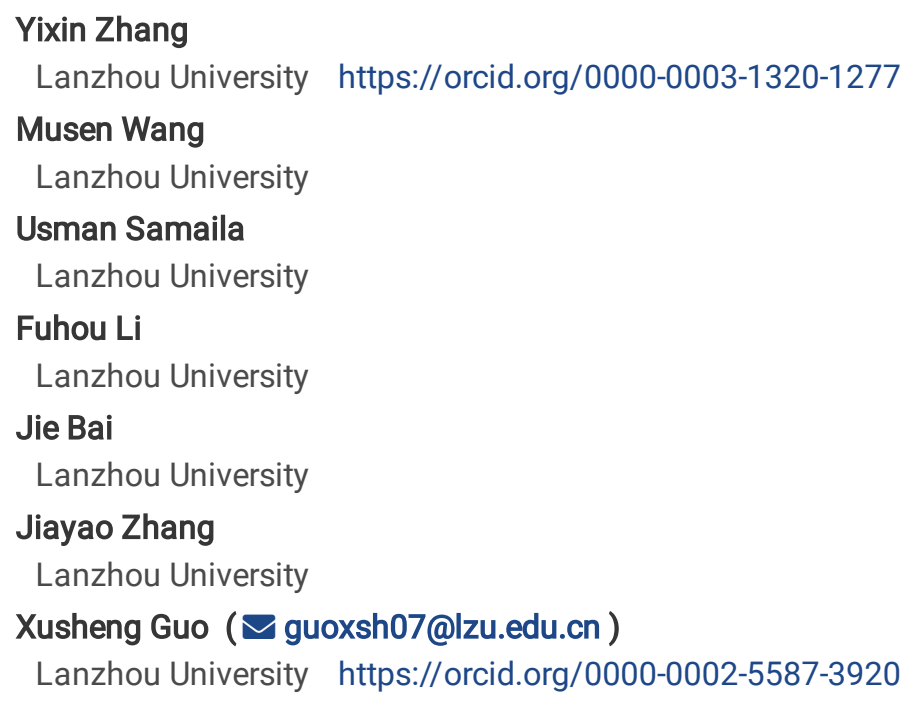

Research

Keywords: Caragana korshinskii Kom., Pediococcus acidilactici, Acremonium cellulase, Silage, Lignocellulosic feedstock, Bacterial community

Posted Date: February 1st, 2022

DOI: https://doi.org/10.21203/rs.3.rs-1282578/v1

License: () (1) This work is licensed under a Creative Commons Attribution 4.0 International License. Read Full License 


\section{Abstract}

The present study investigated the effects of Pediococcus acidilactici and an exogenous fibrolytic enzyme on fermentation profile, structural carbohydrates degradation, enzymatic saccharification, and dynamics of the bacterial community of Caragana korshinskii silage. Chopped C. korshinskii was either not treated (control) or treated with $P$. acidilactici (PA) at 100,000 colony-forming units/g fresh weight; Acremonium cellulase (AC) at $0.3 \mathrm{~g} / \mathrm{kg}$ fresh weight; or a combination of $P$. acidilactici and Acremonium cellulase (PA+AC). Each treatment was prepared in quadruplicate and ensiled in mini-silo bags for 3, 7, 14, 30, and $60 \mathrm{~d}$, respectively. After $60 \mathrm{~d}$ of ensiling, all additives increased lactic acid and acetic acid concentrations $(P<0.001)$ and decreased propionic acid, non-protein nitrogen (NPN), and ammonia nitrogen $\left(\mathrm{NH}_{3}-\mathrm{N}\right)$ concentrations $(P<0.001)$ compared with the control. Meanwhile, the highest lactic and acetic acids and lowest non-protein nitrogen (NPN) and ammonia nitrogen $\left(\mathrm{NH}_{3}-\mathrm{N}\right)(P<0.001)$ were observed in PA+AC treated silage. In addition, the application of additives decreased the silage $\mathrm{pH}$ values during the early-to-mid stage ( 3 to $30 \mathrm{~d}$ ) with the PA+AC group having the lowest value. Compared with the control, all treatments increased ferulic acid concentration and degradation of neutral detergent fiber (NDF) and acid detergent lignin (ADL) at $60 \mathrm{~d}$, meanwhile, the highest values $(P<0.05)$ were obtained from PA+AC silage. PA treatment exhibited a lower performance in the degradation of structural carbohydrates but performed the best in glucose yield and cellulose conversion $(P<0.05)$. The bacterial community in all silages consisted mainly of $P$. acidilactici over the entire fermentation process, and the highest abundance of 6-phospho-beta-glucosidase was observed in PA treated-silage at the mid-later stage of ensiling. These results indicate that pretreating $C$. korshinskii improved its silage quality and potential use as a lignocellulosic feedstock for the production of bio-product and biofuel.

\section{Introduction}

Energy security becomes the dominant issue for developing countries, due to increasing global warming and climate change (Ranjan and Moholkar 2012; Alper and Stephanopoulos 2009). Renewable energy resources, such as crop straw, agricultural residues, and energy plants, are widely used in addressing environmental problems and fuel production (Abraham et al. 2020). Lignocellulosic biomass as the most abundant renewable energy resource help to circumvent the competition with cereals in biofuel production (Birgen et al. 2021). Caragana korshinskii Kom., a forage shrub species for vegetation rehabilitation, is widely planted to generally prevent and control desertification in the arid and semi-arid regions of China (Li et al. 2021). More than 4 million tons of $C$. korshinskii stubble are being generated annually in China after the stems are cut back to give way for new regrowth and make the plant flourish (Li et al. 2021). As shown in some studies, $C$. korshinskii exhibited great potential for silage making and as a feedstock for biofuel production (Zhang et al. 2009; Li et al. 2021). However, the utilization efficiency of $C$. korshinskii is not always satisfactory owing to the high lignin content and the complex fiber structure (Xu et al. 2006). In addition, like other highly putrescent materials, C. korshinskii also faces storge and biotransformation challenges, which requires efficient preservation and pretreatment methods for this material to achieve a year-round operation.

Microbial anaerobic fermentation is considered an effective pretreatment method that was applied to preserve and provide high-quality feedstock for animal and biofuel production (Alper and Stephanopoulos 2009; Liu et al. 2019). However, C. korshinskii is difficult to be ensiled due to the higher buffer capacity and crude fiber content (Ke et al. 2017; Li et al. 2021). Meanwhile, ingestion, digestion, and absorbption of C. korshinskii are restricted for animals due to the existence of thorns and volatiles like tannin (Jurado et al. 2009; Li et al. 2020). Preparing $C$. korshinskii as silage can preserve its nutrients and soften the stipule thorn, improve its palatability (Zhang et al. 2009), and further enhance the quality of milk and meat when fed to animals (Nolan et al. 2010). Therefore, it is necessary to explore effective methods to break the fibrous structure of $C$. korshinskii. Various silage inoculants and exogenous cellulases have been applied to improve fermentation quality by accelerating acidolysis or enzymolysis to decrease the structural complexity of the cell wall (Khota et al. 2016; Li et al. 2018; Liu et al. 2019). Many additives, such as molasses, organic acid, and fibrolytic enzyme, have been used in pretreating lignocellulosic materials to preserve nutrients and enhance fiber degradation (Desta et al. 2016; Liu et al. 2019). Different studies about the application of lactic acid bacteria (LAB) and cellulose enzymes have been explored to degrade the cell wall of herbage, enhance the degradation of fiber and improve the ruminal digestibility of silage (Khota et al. 2016; Li et al. 2020). Pediococcus acidilactici as a homofermentative LAB, can grow rapidly and produce lactic acid at high $\mathrm{pH}$ to inhibit spoilage organisms when compared with other bacterial strains, thereby improving fermentation quality and enhancing fiber degradability (Porto et al. 2017; Alhaag et al. 2019; Zhang et al. 2020). Hence, the sole application of $P$. acidilactici can initiate fermentation quickly at the early stage of ensiling (Yang et al. 2019; Bai et al. 2021), while the combination of $P$. acidilactici and cellulase could be an effective way to improve fiber degradability and fermentation quality. We hypothesized that the application of a rapid start-up LAB alone, or in combination with cellulase, before ensiling could either improve fermentation quality or promote fiber degradability as well as reduce 
the loss of nutrients of the ensiled forage. To our best knowledge, however, far less seems to be known about the effects of $P$. acidilactici and cellulase on the fermentation profile, the fiber degradation, and the bacterial community of $C$. korshinskii silage. Therefore, the objective of this study was to evaluate the fermentation profile, structural carbohydrates degradation, and enzymatic saccharification of $C$. Korshinskii silage treated with a rapid start-up Pediococcus acidilactici strain and an exogenous cellulose enzyme.

\section{Materials And Methods}

\section{Feedstocks and silage additives}

Branches (with leaves and pods) of $C$. korshinskii were manually harvested at the podding stage from Yuzhong County, Gansu Province, China $\left(35^{\circ} 85^{\prime} \mathrm{N}, 104^{\circ} 12^{\prime} \mathrm{E}\right)$ on 19 June 2020. P. acidilactici and Acremonium cellulase (AC, Meiji Seika Pharma Co., Ltd, Tokyo, Japan) were applied as silage additives and were supplied as freeze-dried powders. The bacterial strain $P$. acidilactici was isolated from corn stalk silage and stored in our laboratory. The viable count of $P$. acidilactici powder was $2.5 \times 10^{11}$ colony-forming units (CFU) per gram. Based on the manufacturer's description, Acremonium cellulase activity was more than $1000 \mathrm{U} / \mathrm{g}$, and the patent formula of plant cell wall-degrading enzymes was composed with $\beta$-Glucanase, $\alpha$-Arazyme, $\alpha$-Galactosidase, $\beta$-Galactosidase, and $\beta$-Xylanase. Before the onset of the experiment, $P$. acidilactici and Acremonium cellulase were stored at $4^{\circ} \mathrm{C}$.

\section{Silage preparation}

Fresh C. korshinskii was taken to the laboratory and chopped into 2 to $3 \mathrm{~cm}$ segments using a manual forage chopper (F80221; Wuyang County Mengba department store, Linyi, China). Subsequently, $C$. korshinskii was mixed into a pile and randomly separated into 84 sub-samples. Four random fresh sub-samples were collected and frozen at $-20^{\circ} \mathrm{C}$ pending further analysis. The remaining 80 sub-samples (4 treatments $\times 5$ time points $\times 4$ replicates) were randomly subject to the following treatments: 1 ) distilled water (control); 2) P. acidilactici (PA); 3) Acremonium cellulase (AC); 4) a combination of $P$. acidilactici and Acremonium cellulase (PA+AC). The application rate of $P$. acidilactici was $1 \times 10^{5} \mathrm{CFU} / \mathrm{g}$ fresh weight (FW). The application rate of commercial cellulase was $0.3 \mathrm{~g} / \mathrm{kg} \mathrm{FW}$ as described by Li et al. (2020). To evenly apply the additives to the chopped forages, each additive was diluted in sterile distilled water $(10 \mathrm{~mL} / \mathrm{kg} \mathrm{FW})$. For the control, the same volume of sterile distilled water was applied. After thorough mixing, all the treated samples were ensiled in mini-silo bags ( 280 mm $\times 320$ mm; Cangzhou Hualiang Packaging Co. Ltd., Hebei, China) and vacuum-sealed with a vacuum sealing machine (DZ400/ZT, Wenzhou Overseas Chinese Packaging machinery factory, Zhejiang, China). The mini-silos were fermented for $3,7,14,30$, and $60 \mathrm{~d}$ at room temperature of $25 \pm 2^{\circ} \mathrm{C}$, respectively.

\section{Chemical and ferulic acid analyses}

To determine the fermentation parameters, the sample $(20 \mathrm{~g})$ from each silo was squeezed with $180 \mathrm{~mL}$ of distilled water in a highspeed blender, then filtered through 4 layers of medical gauze. The filtrate was divided into 2 portions. The first portion was acidized to a pH of around 2.0 by $\mathrm{H}_{2} \mathrm{SO}_{4}(7.14 \mathrm{M})$ immediately after measuring the silage $\mathrm{pH}$. The acidized liquid was filtered through a $0.22-$ $\mu \mathrm{m}$ filter for the determination of organic acids (lactic, acetic, propionic, and butyric acids) according to the method of Zhang et al. (2021). Another portion of the filtrate was mixed with trichloroacetic acid $(25 \%, \mathrm{w} / \mathrm{v})$ at a ratio of $1: 4(\mathrm{v} / \mathrm{v})$ and stood for $1 \mathrm{~h}$ at room temperature for deposing the true protein. Subsequently, after $15 \mathrm{~min}$ of centrifugation at $18,000 \times \mathrm{g}$ at $4^{\circ} \mathrm{C}$, the supernatant was analyzed for ammonia nitrogen ( $\left.\mathrm{NH}_{3}-\mathrm{N}\right)$ and water-soluble carbohydrates (WSC) following the procedure of Thomas (1977), and nonprotein nitrogen (NPN) was measured as described by Licitra et al. (1996).

To measure the dry matter (DM) content, fresh and silage samples were dried for $72 \mathrm{~h}$ at $65^{\circ} \mathrm{C}$ by using a thermostatic drying oven (Y101A-4, Changzhou Depu Textile Technology Co. Ltd., Jiangsu, China) and ground through a 1-mm sieve for nutrient analyses according to AOAC (2005). Total nitrogen was determined by the Automatic Kjeldahl apparatus (K9840, Hannon instrument Co. Ltd., Jinan, China), and crude protein (CP) was estimated via total nitrogen $\times 6.25$. The contents of neutral detergent fiber (aNDF), acid detergent fiber (ADF), and acid detergent lignin (ADL) were measured according to the methods of Robertson and Van Soest (1981) using a fiber analyzer (A2000I, Ankom Technology, Fairport, NY). Heat-stable $\alpha$-amylase was used during aNDF analysis. Hemicellulose and cellulose contents were calculated in line with Li et al. (2020). Ferulic acid was extracted and determined as described in the method of Zhao et al. (2014).

\section{Bacterial community composition SMRT analysis}

Page $3 / 20$ 
The bacterial profile of silages was revealed at species level throughout the single molecule real-time sequencing technology (SMRT). Total bacteria DNA extraction of fresh and ensiled C. korshinskii was performed with a TIANamp Bacteria DNA Kit (DP302-02, Tiangen Biotech Co., Ltd. Beijing, China) according to the manufacturer's protocol. The concentration of extracted DNA samples was determined using a Thermo Fisher NanoDrop instrument (ND-2000, United States). The PCR amplification of the bacterial 16S rRNA gene was carried out by using primers 27F (5'-GRGTTYGATYMTGGCTCAG-3') and 1492R (5'-RGYTACCTTGTTACGACTT-3'). The bacterial 16S amplification program was conducted following the description of Zhou et al. (2020). Sequencing of the amplicons and data analysis was carried out on a PacBio platform (Pacific Biosciences, Menlo Park, CA, United States) by the company of Wuhan Frasergen Bioinformatics Co., Ltd. (Wuhan sector, China, in the year 2020.)

\section{Enzymatic saccharification of silages}

The enzymatic saccharification of $C$. Korshinskii silage was conducted after 60 days of ensiling using the Laboratory Analytical Procedure of the National Renewable Energy Laboratory (Resch et al. 2015) with minor modification. Dried sample (0.3 g on DM basis) was dissolved in $5 \mathrm{~mL}$ sodium citrate buffer $(0.1 \mathrm{M}, \mathrm{pH} 5.0)$ which contained Acremonium cellulase $(1 \mathrm{mg} / \mathrm{mL})$ based on cellulose content. A $200 \mu \mathrm{L}$ of $2 \%$ sodium azide solution was added to avoid microbial contamination. Distilled water was supplemented to bring the total volume to $10 \mathrm{~mL}$ before the incubation. Another tube was used as substrate blank with the same dried biomass, the same volume of buffer, antimicrobial agent, and distilled water. An enzyme blank was also prepared in another tube with buffer, azide solution, water, and enzyme solution. All tubes were incubated in a constant temperature shaker for $72 \mathrm{~h}$ at $50^{\circ} \mathrm{C}$ and $160 \mathrm{rpm}$. At each $12 \mathrm{~h}$ interval, sampled and then terminated the reaction at $100^{\circ} \mathrm{C}$ for $10 \mathrm{~min}$. The glucose and xylose were determined by an Agilent high-performance liquid chromatography 1200 (Agilent Technologies, Inc., Germany; column: Carbomix H-NP10, Sepax Technologies, United States; detector: Refractive Index Detector, Agilent Technologies, Inc., Germany; eluent: $0.6 \mathrm{~mL} / \mathrm{min}, 2.5 \mathrm{mM}$ $\mathrm{H}_{2} \mathrm{SO}_{4}$; temperature: $55^{\circ} \mathrm{C}$ ) after centrifugation at $10,000 \times \mathrm{g}$ for $10 \mathrm{~min}$ and filtered through a $0.22-\mu \mathrm{m}$ filter membrane.

\section{Statistical analysis}

General linear model procedure of the SPSS 21.0 (Inc., Chicago, IL, United States) was used to analyze the data of fermentation parameters, chemical composition, and ferulic acid content according to $4 \times 5$ factorial experiment model: $Y_{i j}=\mu+E_{i}+T_{j}+(E \times T)_{i j}+e_{i j}$, where $Y_{i j}=$ response variable; $\mu$ = overall mean; $E_{i}=$ effect of the ensiling times $(i=1,2,3,4,5) ; T_{j}=$ effect of additive treatments $(j=1$,

$2,3,4) ;(E \times T)_{i j}=$ effect of interaction between the ensiling time and additive treatment, and $e_{i j}$ was the residual error. Differences in the $\mathrm{pH}$, structural carbohydrates, ferulic acid, and nonstructural carbohydrate content within the same hydrolysis time were analyzed by one-way ANOVA, and the significance was declared at $P<0.05$.

\section{Results}

\section{Fermentation and chemical characteristics of $C$. korshinskii before ensiling and ensiled for $60 \mathrm{~d}$}

The chemical composition of fresh $C$. korshinskii is shown in Table 1. The fresh $C$. korshinskii exhibited a DM content of $551 \pm 7.57$ $\mathrm{g} / \mathrm{kg}$ FW before ensiling, and the $\mathrm{pH}$ value was $6.35 \pm 0.01$. The concentrations of aNDF, ADF, ADL, hemicellulose, and cellulose were quantified before ensiling, which were $335 \pm 3.78,215 \pm 3.56,57.5 \pm 1.12,120 \pm 7.34$, and $158 \pm 2.46 \mathrm{~g} / \mathrm{kg} \mathrm{DM}$, respectively. In addition, ferulic acid concentration was $1091 \pm 1.01 \mathrm{mg} / \mathrm{kg}$ DM. 
Chemical characteristics of freshly chopped C. korshinskii before ensiling

\begin{tabular}{|c|c|}
\hline Item ${ }^{1}$ & Value $^{2}$ \\
\hline $\mathrm{DM}$ (g/kg FW) & $551 \pm 7.57$ \\
\hline $\mathrm{pH}$ & $6.35 \pm 0.01$ \\
\hline WSC (g/kg DM) & $17.3 \pm 0.02$ \\
\hline $\mathrm{CP}(\mathrm{g} / \mathrm{kg} \mathrm{DM})$ & $202 \pm 0.50$ \\
\hline NPN (g/kg TN) & $114 \pm 1.62$ \\
\hline $\mathrm{NH}_{3}-\mathrm{N}(\mathrm{g} / \mathrm{kg} \mathrm{TN})$ & $1.53 \pm 0.11$ \\
\hline aNDF (g/kg DM) & $335 \pm 3.78$ \\
\hline ADF (g/kg DM) & $215 \pm 3.56$ \\
\hline ADL (g/kg DM) & $57.5 \pm 1.12$ \\
\hline Hemicellulose (g/kg DM) & $120 \pm 7.34$ \\
\hline Cellulose (g/kg DM) & $158 \pm 2.46$ \\
\hline Ferulic acid (mg/kg DM) & $1091 \pm 1.01$ \\
\hline \multicolumn{2}{|c|}{$\begin{array}{l}{ }^{1} \mathrm{DM} \text {, dry matter; FW, fresh weight; WSC, water-soluble carbohydrates; } \mathrm{CP} \text {, crude protein; } \mathrm{NPN} \text {, non-protein nitrogen; } \mathrm{NH}_{3}-\mathrm{N} \text {, ammoni } \\
\text { nitrogen; aNDF, neutral detergent fiber assayed with a heat-stable amylase and expressed inclusive of residual ash; } \mathrm{ADF} \text {, acid } \\
\text { detergent fiber; } \mathrm{ADL} \text {, acid detergent lignin. }\end{array}$} \\
\hline
\end{tabular}

The fermentation and chemical characteristics of $C$. korshinskii silage are shown in Table 2. There were significant effects of additives on lactic acid, acetic acid, and propionic acid contents of the silages. Although all additives enhanced lactic acid and acetic acid contents when compared to the control, PA+AC treatment resulted in the highest lactic acid and acetic acid contents, an opposite trend was observed in propionic acid content $(P<0.001)$. Butyric acid was not traced in any treatment. The highest DM content was recorded in PA group, and the highest DM loss was recorded in the control group. A significant effect $(P<0.001)$ of additives was also observed on the WSC of $C$. korshinskii silages in the present study. In contrast to the control, the addition of AC showed the highest WSC content while sole application of $P$. acidilactici had the lowest WSC content. The silages treated with PA and AC had higher CP content compared to the control silage, but no difference was found among PA+AC and other silages. The lowest contents of $\mathrm{NPN}$ and $\mathrm{NH}_{3}-\mathrm{N}$ were observed from silages inoculated with the combination of $P$. acidilactici and Acremonium cellulase. There were dynamic effects of additives and ensiling time on $\mathrm{pH}$ (Fig. 1A). The addition of $P$. acidilactici and commercial cellulase (PA-, AC- and PA+AC- treated silages) decreased the $\mathrm{pH}$ values at the initial stage of ensiling (3 d), especially in $P$. acidilactici treatments (PA- and PA+AC- treated silages). Subsequently, the $\mathrm{pH}$ values declined continuously and had a significant difference among the treatments until $30 \mathrm{~d}$, and the lowest $\mathrm{pH}$ value was observed in PA+AC treated silage. The $\mathrm{pH}$ values of $C$. korshinskii silages at $60 \mathrm{~d}$ were all below 4.95, the addition of $\mathrm{AC}$ and PA+AC significantly decreased the $\mathrm{pH}$ values compared with the control and PA groups after $60 \mathrm{~d}$ of ensiling. 
Table 2

Fermentation and chemical characteristics of ensiled C. korshinskii (60 d) as influenced by additives

\begin{tabular}{|c|c|c|c|c|c|c|}
\hline \multirow[t]{2}{*}{ Item $^{1}$} & \multicolumn{4}{|c|}{ Treatment $^{2}$} & \multirow[t]{2}{*}{ SEM $^{3}$} & \multirow[t]{2}{*}{$P$-value } \\
\hline & control & PA & $A C$ & $P A+A C$ & & \\
\hline Lactic acid (g/kg DM) & $32.2^{\mathrm{c}}$ & $33.9^{\mathrm{b}}$ & $35.1^{\mathrm{b}}$ & $42.8^{\mathrm{a}}$ & 1.067 & $<0.001$ \\
\hline Acetic acid (g/kg DM) & $18.9^{\mathrm{c}}$ & $20.9^{\mathrm{b}}$ & $21.2^{\mathrm{b}}$ & $25.3^{a}$ & 0.636 & $<0.001$ \\
\hline Propionic acid (g/kg DM) & $17.0^{\mathrm{a}}$ & $11.9^{\mathrm{b}}$ & $10.1^{\mathrm{c}}$ & $10.7^{\mathrm{c}}$ & 0.716 & $<0.001$ \\
\hline DM (g/kg FW) & $549^{b}$ & $561^{a}$ & $540^{\mathrm{b}}$ & $546^{b}$ & 2.207 & 0.001 \\
\hline DM loss (g/kg DM) & $22.5^{\mathrm{a}}$ & $21.1^{\mathrm{ab}}$ & $18.8^{\mathrm{b}}$ & $20.2^{\mathrm{ab}}$ & 0.307 & 0.008 \\
\hline WSC (g/kg DM) & $0.84^{b}$ & $0.58^{c}$ & $1.99^{a}$ & $0.84^{b}$ & 0.008 & $<0.001$ \\
\hline $\mathrm{CP}(\mathrm{g} / \mathrm{kg} \mathrm{DM})$ & $204^{b}$ & $207^{a}$ & $208^{a}$ & $206^{\mathrm{ab}}$ & 0.540 & 0.006 \\
\hline NPN (g/kg TN) & $441^{a}$ & $427^{b}$ & $418^{c}$ & $347^{d}$ & 9.355 & $<0.001$ \\
\hline $\mathrm{NH}_{3}-\mathrm{N}(\mathrm{g} / \mathrm{kg} \mathrm{TN})$ & $31.0^{\mathrm{a}}$ & $26.9^{\mathrm{b}}$ & $23.5^{\mathrm{c}}$ & $21.0^{\mathrm{d}}$ & 0.974 & $<0.001$ \\
\hline \multicolumn{7}{|c|}{$\begin{array}{l}{ }^{1} \mathrm{DM} \text {, dry matter; FW, fresh weight; WSC, water-soluble carbohydrate; } \mathrm{CP} \text {, crude protein; } \mathrm{NPN} \text {, non-protein nitrogen; } \mathrm{NH}_{3}-\mathrm{N} \text {, ammon } \\
\text { nitrogen. }\end{array}$} \\
\hline \multicolumn{7}{|c|}{$\begin{array}{l}{ }^{2} \mathrm{PA}, P \text {. acidilactici; AC, Acremonium cellulase; PA+PC, a combination of } P \text {. acidilactici and Acremonium cellulose; Means with } \\
\text { different letters in the same row }(\mathrm{a}-\mathrm{d}) \text { indicate a significant difference }(P<0.05)\end{array}$} \\
\hline
\end{tabular}

\section{Dynamics of structural carbohydrates during C. korshinskii ensiling process}

The effects of additives and ensiling time on the dynamics of aNDF, ADF, ADL, hemicellulose, and cellulose of $C$. Korshinskii silage are shown in Fig. 1B-F. Throughout the fermentation period, ensiling times and additives contributed to the complexity of the structural carbohydrates' changes. At the early stage of ensiling ( $3 \mathrm{~d})$, the AC and PA+AC treated silages had a conspicuous decrease in aNDF and ADF contents, but an opposite result was observed in ADL content (Fig. 1B, 1C, and 1D). Compared to control and other additives treatments, the addition of PA led to a huge reduction in the content of aNDF with advancing ensiling time until $14 \mathrm{~d}$, and a decreasing trend was found in all treatments. As the ensiling time reached the mid-fermentation (30 d), there was an obvious difference in aNDF among all the treatments up to the end of the ensiling time of our study. However, the application of PA+AC showed the lowest content of aNDF at the end of the fermentation. The effects of $P$. acidilacticion aNDF maintained a plateau form the mid up to the end of the ensiling time, with a lower concentration compared to the control and AC treated silages. The control silage had the highest ADF content throughout the fermentation period compared to other treatments $(P<0.05)$. No difference was observed in ADF among PA, AC, and PA+AC treatments at $7 \mathrm{~d}$, but a marked difference appeared continuously with the advancing period of ensiling. The PA+AC treatment showed the lowest content of ADF from 14 to $60 \mathrm{~d}$ of fermentation. The higher content of ADL was obtained after the addition of $P$. acidilactici combined with Acremonium cellulase throughout the ensiling process except for the $30 \mathrm{~d}$, and the trend was comparable with the group of PA which declined to the lowest at $30 \mathrm{~d}$. With the advancement in the fermentation period, differences among treatments were obtained in hemicellulose and cellulose contents (Fig. 1E and 1F). At the initial stage of ensiling, PA and AC treated silages had the higher content of hemicellulose, subsequently, AC and PA+AC groups showed higher content of hemicellulose than control and PA treatments from 7 to $14 \mathrm{~d}$. At $30 \mathrm{~d}$, the hemicellulose content was significantly different among the four treatments. The PA-treated silage had the lowest hemicellulose content than other treatments after 30 and $60 \mathrm{~d}$ of ensiling. In addition, the trend in cellulose content was similar to that of the ADF.

\section{Concentration of ferulic acid during C. korshinskii ensiling period}

The effects of additives and ensiling time on ferulic acid are presented in Fig. 2. The figure revealed that the effects are significant throughout the ensiling time. At the initial phase of ensiling ( $3 \mathrm{~d})$, the addition of $P$. acidilactici with commercial cellulase had a higher 
ferulic acid concentration $(1155 \mathrm{mg} / \mathrm{kg} \mathrm{DM}, P<0.05)$ while no significant difference appeared among other groups. At 7 and $14 \mathrm{~d}$, the highest concentration of ferulic acid was found in PA treated silage, implying that the $P$. acidilactici strain contributed to the dramatic

increase in the concentration of ferulic acid. Meanwhile, the ferulic acid concentration of AC treated silage declined at $14 \mathrm{~d}$ of ensiling, and there was no difference between the control and PA+AC treated silages. An increasing trend was observed in the AC and PA+AC groups in the mid-stage of ensiling, and the highest ferulic acid content $(1155 \mathrm{mg} / \mathrm{kg} \mathrm{DM}, P<0.05)$ was detected when the mixture of $P$. acidilactici and commercial cellulase was added compared to other silages. The concentration of ferulic acid had been on a plateau during the initial and mid ensiling phases of control and PA treatments. As the fermentation advances to the end of ensiling, the trends remain similar for the ensiling time at 30 and $60 \mathrm{~d}$ except for control silage where ferulic acid concentration declined. The PA+AC treatment had the highest ferulic acid content $(1215 \mathrm{mg} / \mathrm{kg} \mathrm{DM}, P<0.05)$ when compared with control, PA, and AC groups after $60 \mathrm{~d}$ ensilage.

\section{Bacterial community composition and functional profiling in C. korshinskii silage}

As shown in Table 3, the alpha diversity of $C$. korshinskii decreased after ensiling. Additives decreased the species richness (Chao 1 , Observed species and ACE) compared with the control at the initial-mid phase of ensiling (3-30 d), whereas PA+AC inoculated silage showed the highest richness among the four groups at the end of the fermentation. PA inoculated silage showed a lower Shannon value when compared with the control after 3 to $14 \mathrm{~d}$ of ensiling, whereas it has a higher Shannon value than the other three groups after $60 \mathrm{~d}$ of ensiling. The Shannon value in AC and PA + AC treated groups was lower than that of the control from 3 to $7 \mathrm{~d}$ of ensiling, and lower than that in the PA inoculated group after 30 and $60 \mathrm{~d}$ of ensiling. In addition, the lowest Shannon value was observed in AC treated group among the four treatments after 30 and $60 \mathrm{~d}$ of ensiling. 
Table 3

Bacterial alpha diversity of fresh and ensiled $C$. korshinskii as influenced by additives and ensiling period

\begin{tabular}{|c|c|c|c|c|c|c|c|c|c|c|c|c|}
\hline \multirow[t]{2}{*}{ Item } & \multirow{2}{*}{$\begin{array}{l}\text { Fresh } \\
\text { forage }\end{array}$} & \multirow{2}{*}{$\begin{array}{l}\text { Treatment } \\
(T)^{1}\end{array}$} & \multicolumn{5}{|c|}{ Ensiling time (E) } & \multirow[t]{2}{*}{ Mean } & \multirow[t]{2}{*}{ SEM $^{2}$} & \multicolumn{3}{|c|}{$P$-value ${ }^{3}$} \\
\hline & & & 3 & 7 & 14 & 30 & 60 & & & $T$ & $E$ & $T \times E$ \\
\hline \multirow[t]{4}{*}{ Chao1 } & 306 & control & $189^{a A}$ & $62.3^{\mathrm{aB}}$ & $53.9^{\mathrm{aC}}$ & $44.2^{\mathrm{aD}}$ & $19.1^{\mathrm{cE}}$ & $73.7^{a}$ & 0.279 & 0.001 & 0.001 & 0.001 \\
\hline & & PA & $55.8^{\mathrm{cA}}$ & $23.1^{\mathrm{cC}}$ & $47.0^{\mathrm{bB}}$ & $21.1^{\mathrm{cC}}$ & $14.0^{\mathrm{dD}}$ & $32.2^{c}$ & & & & \\
\hline & & $A C$ & $101^{\mathrm{bAB}}$ & $38.4^{b}$ & $41.5^{\mathrm{bB}}$ & $28.0^{\mathrm{bC}}$ & $26.1^{\mathrm{bC}}$ & $46.9^{b}$ & & & & \\
\hline & & $P A+A C$ & $22.0^{\mathrm{dB}}$ & $23.0^{\mathrm{cB}}$ & $11.8^{\mathrm{cD}}$ & $17.8^{\mathrm{cC}}$ & $42.1^{\mathrm{aA}}$ & $23.3^{d}$ & & & & \\
\hline \multirow[t]{4}{*}{ Shannon } & 5.56 & control & $2.49^{\mathrm{aA}}$ & $0.84^{\mathrm{aB}}$ & $0.77^{\mathrm{aBC}}$ & $0.67^{\mathrm{bc}}$ & $0.66^{\mathrm{bC}}$ & $1.09^{a}$ & 0.005 & 0.001 & 0.001 & 0.001 \\
\hline & & PA & $0.83^{\mathrm{bA}}$ & $0.57^{\mathrm{CB}}$ & $0.52^{\mathrm{bB}}$ & $0.74^{\mathrm{aA}}$ & $0.72^{\mathrm{aA}}$ & $0.67^{b}$ & & & & \\
\hline & & $\mathrm{AC}$ & $0.89^{\mathrm{bA}}$ & $0.76^{\mathrm{bB}}$ & $0.70^{\mathrm{aC}}$ & $0.59^{\mathrm{cD}}$ & $0.57^{\mathrm{CD}}$ & $0.70^{\mathrm{b}}$ & & & & \\
\hline & & $P A+A C$ & $0.80^{\mathrm{bA}}$ & $0.76^{\mathrm{bA}}$ & $0.75^{\mathrm{aA}}$ & $0.65^{\mathrm{bcB}}$ & $0.60^{\mathrm{cB}}$ & $0.71^{b}$ & & & & \\
\hline \multirow[t]{4}{*}{$\begin{array}{l}\text { Observed } \\
\text { species }\end{array}$} & 273 & control & $133^{\mathrm{aA}}$ & $46.0^{\mathrm{aB}}$ & $39.0^{\mathrm{aB}}$ & $26.0^{\mathrm{aC}}$ & $18.0^{\mathrm{bC}}$ & $52.4^{\mathrm{a}}$ & 0.384 & 0.001 & 0.001 & 0.001 \\
\hline & & PA & $29.0^{\mathrm{cA}}$ & $16.0^{\mathrm{cB}}$ & $9.00^{\mathrm{cB}}$ & $13.0^{\mathrm{bB}}$ & $12.0^{\mathrm{cB}}$ & $15.7^{c}$ & & & & \\
\hline & & $\mathrm{AC}$ & $70.0^{\mathrm{bA}}$ & $26.0^{\mathrm{bB}}$ & $16.0^{\mathrm{bD}}$ & $15.0^{\mathrm{bD}}$ & $20.0^{\mathrm{bC}}$ & $29.4^{\mathrm{b}}$ & & & & \\
\hline & & $P A+A C$ & $15.0^{\mathrm{dB}}$ & $12.0^{\mathrm{dB}}$ & $10.0^{\mathrm{cB}}$ & $12.0^{\mathrm{bB}}$ & $33.0^{\mathrm{aA}}$ & $16.4^{\mathrm{C}}$ & & & & \\
\hline \multirow[t]{4}{*}{ ACE } & 322 & control & $210^{\mathrm{aA}}$ & $81.0^{\mathrm{aB}}$ & $65.4^{\mathrm{aB}}$ & $64.8^{\mathrm{aB}}$ & $28.0^{\mathrm{bC}}$ & $89.8^{a}$ & 0.811 & 0.001 & 0.001 & 0.001 \\
\hline & & PA & $49.6^{\mathrm{cA}}$ & $41.6^{\mathrm{bA}}$ & $13.3^{\mathrm{cB}}$ & $27.7^{\mathrm{CAB}}$ & $26.8^{\mathrm{bAB}}$ & $31.8^{\mathrm{c}}$ & & & & \\
\hline & & $\mathrm{AC}$ & $101^{\mathrm{bA}}$ & $43.1^{\mathrm{bB}}$ & $50.0^{\mathrm{bB}}$ & $40.5^{\mathrm{bBC}}$ & $29.5^{\mathrm{bC}}$ & $52.8^{\mathrm{b}}$ & & & & \\
\hline & & $P A+A C$ & $26.7^{\mathrm{dB}}$ & $33.6^{\mathrm{bB}}$ & $15.0^{\mathrm{cC}}$ & $28.0^{\mathrm{cB}}$ & $47.8^{\mathrm{aA}}$ & $30.2^{c}$ & & & & \\
\hline \multicolumn{13}{|c|}{$\begin{array}{l}{ }^{1} \mathrm{PA}, P \text {. acidilactici; } \mathrm{AC}, \text { Acremonium cellulase; } \mathrm{PA}+\mathrm{PC} \text {, a combination of } P \text {. acidilactici and Acremonium cellulose; Means with } \\
\text { different letters in the same row }(\mathrm{A}-\mathrm{E}) \text { or column }(\mathrm{a}-\mathrm{d}) \text { indicate a significant difference }(P<0.05) .\end{array}$} \\
\hline \multicolumn{13}{|c|}{${ }^{2} S E M$, standard error of the mean. } \\
\hline
\end{tabular}

The composition of the bacterial community is shown in Fig. 3A. The epiphytic microflora before ensiling was more complex, primarily comprised Variovorax boronicumulans (5.30\%), Methylobacterium goesingense (4.36\%), P. acidilactici (2.37), and others (69.48\%) at the species level. Regardless of pretreatment, the relative abundance of $P$. acidilactici dramatically increased and dominated the bacterial community of all the silages after $3 \mathrm{~d}$. In addition to $P$. acidilactici, there were undesirable bacteria such as Erwinia tasmaniensis in the control after $3 \mathrm{~d}$ of ensiling. As the ensiling period advanced from 7 to $60 \mathrm{~d}, P$. acidilactici became the predominant species (> 97\%) in the $C$. korshinskii silage treated with or without additives. The linear discriminant analysis effect size (LEfSe) analysis was used to explore the differences in bacterial communities of the four $C$. korshinskii silage groups during the ensiling (Fig. 3B). By comparing with the control, the application of additives inhibited the growth of undesirable bacteria during the ensiling periods from 3 to $30 \mathrm{~d}$. The relative abundance of $P$. acidilactici was significantly higher in PA inoculated silage after 3 and $7 \mathrm{~d}$ of ensiling, and Lactobacillus paracasei became the significantly abundant species in PA inoculated silage from 14 to $60 \mathrm{~d}$ of ensiling. In the AC treated silage, Rhizobium soli was higher after $3 \mathrm{~d}$ of ensiling, and P. acidilactici and Lactobacillus fermentum were higher after 30 and $60 \mathrm{~d}$ of ensiling, respectively. Interestingly, the undesirable bacteria such as Bacillus horikoshii were higher in PA+AC treated silage after $60 \mathrm{~d}$ of ensiling. The microbial networks of $C$. korshinski silage were calculated based on the 16S rRNA gene from the bacteria with a relative abundance greater than $0.001 \%$ (Fig. 3C). Simple microbial networks were observed in silages treated with additives, especially in PA inoculated silage. P. acidilactici was positively correlated with B. horikoshii in PA inoculated silage, while 
negatively correlated with $B$. horikoshii and other undesirable bacterial species in AC and PA+AC treated silage. The interaction between $P$. acidilactici and other bacterial species was complicated in the control.

The four KEGG pathways were used to observe functional shifts, which were cellular processes, environmental information processing, genetic information processing, and metabolism, among the bacterial community of the four treatments (Fig. 4A). The relative abundances of cellular community and amino acid metabolism in the control were higher than those in additive treated groups at the initial stage of fermentation $(3,7$, and $14 \mathrm{~d})$, while the highest relative abundances were observed in the PA+AC at the $60 \mathrm{~d}$ of ensiling. In addition, the relative abundances of membrane transport, nucleotide metabolism, and carbohydrate metabolism were lower in the control than in the other three groups from 3 to $14 \mathrm{~d}$ of ensiling, while PA+AC inoculated silage showed the lowest relative abundances among the four treatments at the end of fermentation point. EC:3.2.1.86 (6-phospho-beta-glucosidase) in enzyme classification (EC) database was chosen to explain the fiber degradation after fermentation (Fig. 4B). The abundance of 6-phospho-beta-glucosidase was higher in PA inoculated silage than in control and AC treated silage during the entire ensiling period except for $14 \mathrm{~d}$ of ensiling. In addition, there were no differences observed in 6-phospho-beta-glucosidase abundance between PA and PA+AC treated silage after 3 and $7 \mathrm{~d}$ of ensiling, while the abundance of 6-phospho-beta-glucosidase was higher in PA inoculated silage than in PA+AC treated silage after ensiling for 30 and $60 \mathrm{~d}$.

\section{The effects of additives on enzymatic saccharification of C. korshinskii silage}

The enzymatic saccharification results of the $60 \mathrm{~d} C$. korshinskii silages are shown in Fig. 5. The application of $P$. acidilactici showed the highest glucose yield $(P<0.05)$ when compared with the other treatments regardless of the hydrolysis times except at $24 \mathrm{~h}$ that had no difference compared with the control (Fig. 5A). Meanwhile, the highest cellulose $(P<0.05)$ conversion was obtained in PA treated silage throughout the incubation period of the enzymatic saccharification, and the lowest cellulose conversion was observed in Acremonium cellulase treated silage except that the treatment was not different from the PA+AC group at $36 \mathrm{~h}$ (Fig. 5C). For the yield of xylose, the control and PA treated silages were higher than AC and PA+AC groups. control silage exhibited the highest concentration of xylose throughout the incubation period, except at $36 \mathrm{~h}$ and no significant difference was found between control and PA treatments at $48 \mathrm{~h}$ (Fig. 5B). The AC and PA+AC groups had similar xylose yields throughout the hydrolysis time.

\section{Discussion}

C. korshinskii, is widely planted in the arid and semi-arid regions of China. However, its low WSC content and the high buffer capacity as well as lignin content make it difficult to be ensiled (Xu et al. 2006; Ke et al. 2017; Li et al. 2021). Inoculating silage with LAB and cellulase was found to ensure good fermentation quality and improve bioconversion efficiency (Li et al. 2020) because LAB can efficiently transform WSC into lactic acid and reduce silage $\mathrm{pH}$ to inhibit the growth of undesirable organisms at the initial stage of ensiling (Li et al. 2019; Bai et al. 2021). Moreover, some inoculants may have the ability to secrete cellulose-related enzymes and cause destruction to the fiber structure of the forage during ensiling (Chen et al. 2018; Liu et al. 2019; Li et al. 2021). Therefore, the addition of lactic acid-producing cocci (Pediococcus) and cellulase as additives should be considered before ensiling. PA treated silage was found to have the lowest WSC content compared to control, AC and PA+AC treated silages in the present study, whereas had higher lactic and acetic acids contents than the control. Studies have shown that LAB strains can decline pH value by accelerating WSC transformation into lactic and acetic acids (Ding et al. 2019; Li et al. 2020; Zhang et al. 2021). However, no differences in pH values were found between control and PA treatments or between AC and PA+AC treatments after $60 \mathrm{~d}$ of ensiling. The most reasonable account was that $P$. acidilactici dominated the silage bacterial community at the early stage of fermentation (Yang et al. 2019; Bai et al. 2021). Cellulase increased lactic acid and acetic acid concentrations, which was consistent with the reports of Li et al. (2018) who reported that the addition of cellulase can promote the production of lactic and acetic acids through lignocellulose hydrolysis. The highest lactic and acetic acids concentrations in PA+AC treated silage could probably be due to direct biodegradation of lignocellulose through the synergistic effects of $P$. acidilactici and cellulase (Oladosu et al. 2016; Li et al. 2020). Generally, propionic acid is produced from secondary fermentation of clostridia by consuming lactic acid (Kung et al. 2008). Application of bacterial inoculant and commercial cellulase decreased propionic acid concentration, suggesting an inhibition of the secondary fermentation which preserved more nutrients excellently (Li et al. 2020). In addition, the low DM losses (<23 g/kg DM) and pH values (< 4.95) further proved that the additives are favorable to $C$. korshinskii ensilage in the present study. After $60 \mathrm{~d}$ of ensiling, $P$. acidilactici had a remarkably higher silage DM content because LAB inhibited the growth and fermentation by spoilage microorganisms, which agrees with our previous study (Zhang et al. 2021). Proteolysis mainly resulted from plant proteases but it could be inhibited by the decline in pH (Ke et al. 2017). The addition of $P$. acidilactici and Acremonium cellulase in the silages resulted in a greater reduction of $\mathrm{NPN}$ and $\mathrm{NH}_{3}-\mathrm{N}$ 
contents after $60 \mathrm{~d}$ of ensiling. In addition, the reduction in $\mathrm{NPN}$ and $\mathrm{NH}_{3}-\mathrm{N}$ contents after inoculation with $P$. acidilactici was mainly attributed to the decline in $\mathrm{pH}$ which occurred at the initial stage.

Many studies revealed that the addition of exogenous fibrolytic enzymes during ensiling can hydrolyze cell walls directly due to cellulase, glucanase, and xylanase activities (Desta et al. 2016; Li et al. 2020). The degradation of fiber (aNDF and ADF) was found in the AC treated group in the present study, which was probably attributed to the coaction of various enzymes. Many studies have found that inoculation with LAB can promote the degradation of lignocellulose (Khota et al. 2016; Li et al. 2020). Zhang et al. (2021) also revealed that $P$. acidilactici $\mathrm{J} 17$ strain which has a high antioxidant capacity enhanced the degradation of aNDF and ADF in alfalfa ensiled at two different DM contents. In this study, the degradation of aNDF, ADF, and cellulose contents in PA treated silage could be attributed to the acid hydrolysis of the structural carbohydrates from the initial to the mid ensiling phase (Desta et al. 2016; Li et al. 2020), or the production of cellulose-related enzymes by P. acidilactici that accelerated the degradation of lignocellulose (Chen et al. 2018). Meanwhile, the most effective reduction of aNDF, ADF, and cellulose contents was in PA+AC treated silage as expected which was attributed to the synergistic effect of cellulase and $P$. acidilactici. The synergistic action contributed by $P$. acidilactici was not only utilizing fermentation substrates hydrolyzed by Acremonium cellulase during ensiling but also hydrolyzed structural carbohydrates through acidolysis or enzymolysis. Moreover, the inability to degrade lignin is the main limitation of animal digestibility and ensilage quality (Desta et al. 2016; Li et al. 2020). In the current study, ADL showed a tendency of continuous decline during ensiling process and reached the lowest at $30 \mathrm{~d}$ in PA treated silage. This further proved that $P$. acidilactici as a fermentation promoter played a role in the fiber degradation at the early stage of ensiling. To further demonstrate the profile of lignocellulose degradation, the content of ferulic acid was determined during ensiling. Cellulose is covered by hemicellulose and lignin which limits the degradation of lignocellulose during ensiling (Pérez et al. 2002), reduces the digestibility and utilization of ruminants, and hinders bioenergy production. Ferulic acid was released after the addition of $P$. acidilactici and Acremonium cellulase primarily through acidolysis and/or enzymatic hydrolysis which break the linkages of the ester bonds. The silage treated with $P$. acidilactici exhibited a higher concentration of ferulic acid at the initial stage of fermentation, which further explained the reduction of aNDF and ADF contents of the silages. As expected, the highest content of ferulic acid was obtained in PA+AC treated silage after $60 \mathrm{~d}$ of ensiling, which is due to the synergistic effects of the additives.

The fermentation quality of silages with or without additives depends on the bacterial composition and changes during the ensiling time. Alpha diversity of $C$. korshinskii decreased after ensiling, and silage with additives had lower alpha diversity at the early stage of fermentation, which may be due to the dramatic decrease in $\mathrm{pH}$. The acidic anaerobic environment after ensiling led to the modification of the bacterial community where most of the epiphytic bacteria disappeared due to low adaptability to low pH (Méndez-García et al. 2015; Zheng et al. 2017; Dong et al. 2020). Although the epiphytic LAB (P. acidilactici) in C. korshinskii before ensiling was the same as the added inoculant, the differences occurred due to the abundance and function. In the present study, the application of $P$. acidilactici decreased the relative abundance of Erwinia tasmaniensis and other epiphytic bacteria after $3 \mathrm{~d}$ of ensiling, and the $P$. acidilactici maintained the highest relative abundance throughout the entire fermentation period. This could be attributed to the adaptability as well as the rapid growth and multiplication of $P$. acidilactici which produces higher lactic acid that swiftly declined the pH to inhibit the growth of spoilage microorganisms throughout the fermentation (Yang et al. 2019; Bai et al. 2021). LEfSe analysis was used to further explore the differences of bacterial community among the control and additive treatments. The application of additives had weakened the growth of epiphytic competitors at the initial-mid stage of ensiling. Subsequently, the competitiveness of some undesirable bacteria such as $B$. horikoshi resulted in the species increase in the PA+AC treatment at the end of ensiling. In the control treatment, other species subsequently decreased while the epiphytic $P$. acidilactici abundance increased with the adaptation to the acidic environment at the end of fermentation. Our previous studies showed that a relatively simple bacterial interaction was attributed to a high fermentation quality, which led to a lower alpha diversity (Xu et al. 2020; Bai et al. 2021). In the current study, the additives simplified the bacterial interaction network after ensiling, especially PA treated silage showed the simplest bacterial interaction network structure which could be due to the coaction of epiphytic and exogenous $P$. acidilactici and result in a better fermentation quality.

The differences in fermentation quality among the different treatments despite having the same dominated bacteria species might be due to the varying degrees of microbial functions and degradation, as well as the transformation of fermentable substrates in the silages. To have a better understanding of regulating bacteria on the silage fermentation, a functional predictive analysis of the metabolic pathway of bacteria was identified by PICRUSt. The metabolisms of nucleotide, carbohydrate, and amino acid were closely related to silage fermentation (Xu et al. 2020; Bai et al. 2021). In the present study, nucleotide and carbohydrate metabolisms were lower in the control at the initial process of silage fermentation and increased with the extension of the fermentation. According to Kilstrup et al. (2005) and Bai et al. (2021), the relative abundances of total LAB in the microbial community are related to the

Page $10 / 20$ 
abundance of nucleotide and carbohydrate metabolism pathways. Based on the bacterial community compositions after ensiling, silages with high relative abundances of nucleotide and carbohydrate metabolisms had a higher relative abundance of $P$. acidilactici. And the relative abundance of carbohydrate metabolism was higher in AC than in the other treatments, which was in line with the higher WSC content. Generally, amino acids are the basic components of proteins and peptides. In this study, a higher relative abundance of amino acid metabolism was observed in the control at $3 \mathrm{~d}$, which suggests that $P$. acidilactici decreased the action of amino acid metabolism in other treatments mainly due to low pH that inhibits the action of protease. There were no differences among control, PA and PA+AC treated silages in amino acid metabolism at the end of ensiling, however, lower CP content and higher $\mathrm{NH}_{3}-\mathrm{N}$ and NPN concentrations were observed in the control. It could be attributed to higher protein degradation and the accumulation of $\mathrm{NH}_{3}-$ $\mathrm{N}$ and NPN contents during the entire process of fermentation, or the different effects of epiphytic and exogenous $P$. acidilactici. EC:3.2.1.86 can catalyze 6-phospho-glucosidase compounds to produce 6-phospho-glucose (Liu et al. 2014; Chen et al. 2018) and it was chosen to further explore the reason for lignocellulose degradation among different additives after ensiling. AC and PA+AC silages had a higher abundance of 6-phospho-beta-glucosidase throughout the ensiling period (except $14 \mathrm{~d}$ ), and PA treated group had the highest abundance of 6-phospho-beta-glucosidase at the mid-later fermentation process of the silage. This also explained the reason for the dramatic decline in aNDF and ADL in PA treated silage which is partly attributed to the role of 6-phospho-beta-glucosidase and acid hydrolysis. The lowest aNDF and ADF observed in the PA+AC was also due to the synergistic effect of 6-phospho-beta-glucosidase and Acremonium cellulase.

Lignocellulosic biomass provides an abundance of cellulose and hemicellulose that can be converted into fermentable sugars during the anaerobic digestion stage. These sugars can further be used to produce bioproducts or biofuels (Fujii et al. 2009; Li et al. 2020). However, the complex structure of lignocellulose results in the underutilization of the biomass by microbes or enzymes. Cellulose is mainly composed of glucose and macromolecular polysaccharides, but hemicellulose is a complex carbohydrate polymer that mainly consisted of glucose and xylose (Pérez et al. 2002). Due to the decrease of sugar loss and production of by-products, the enzymatic digestibility of lignocellulose remains the best way to decrease environmental pollution (Shinozaki and Kitamoto 2011). Pretreatment of forage before enzymatic saccharification is an effective method to improve the cellulose conversion efficiency, mainly through breaking the structural linkage (Desta et al. 2016; Li et al. 2018). In the present study, C. korshinskii with or without additives presented different yields of reducing sugars after hydrolysis. The PA-treated silage had the highest glucose yield and cellulose conversion throughout the hydrolysis time. It could be due to acid hydrolysis and cellulose-related enzymatic hydrolysis of $P$. acidilactici strain that modified the lignocellulosic structure in the initial process of ensiling (Desta et al. 2016; Chen et al. 2018). This also could be illustrated by the dramatic decline in aNDF and ADL at the early-to-mid stage of ensilage. According to Li et al. (2019), inoculating corn stalk with ferulic acid esterase producing $L$. plantarum A1 showed the highest glucose yield and cellulose convertibility during the enzymatic saccharification. When compared to control and PA treatments, lower glucose and xylose yields, as well as the cellulose conversion was observed in PA+AC treatment during the hydrolysis time. The most reasonable explanation is that forage applied with exogenous $P$. acidilactici strain and cellulase result in lignocellulosic biomass (the most soluble structural polysaccharides portion) is digested, and the rest of the portions which are harder to hydrolyze that can resist the degradation process (Dehghani et al. 2012; Li et al. 2019). Therefore, the highest ADL content was observed in PA+AC treated silage at early-to-mid and $60 \mathrm{~d}$ of fermentation time. Meanwhile, the highest decline in structural carbohydrates (aNDF and ADF) of PA+AC treated silage might contribute to cellulose biomass aggregation across the ensiling period, which can enhance fiber strength as well as resist to enzyme action (Desta et al. 2016; Phitsuwan et al. 2016; $\mathrm{Li}$ et al. 2019). In addition, silages with no additive exhibited a higher xylose yield than AC and PA+AC treatments, it might be because of the highest contents of aNDF and ADF after $60 \mathrm{~d}$ of ensiling, and they were easier to hydrolyze into xylose during enzymatic saccharification experiment.

\section{Conclusions}

After $60 \mathrm{~d}$ of ensiling, all additives improved the fermentation quality, as seen in higher lactic and acetic acids contents, and decreased $\mathrm{NPN}$ and $\mathrm{NH}_{3}-\mathrm{N}$ concentrations of the silage. All additives also decreased the $\mathrm{pH}$ value, with PA+AC treated silage having the lowest $\mathrm{pH}$ at the early-to-mid ensiling period. Application of $P$. acidilactici and fibrolytic enzyme increased the ferulic acid content and digestibility of aNDF and ADL after $60 \mathrm{~d}$ of fermentation, hence, the highest ferulic acid content and lowest aNDF, ADL, and cellulose contents were observed in the PA+AC treated silage. PA treated silage had the highest lignocellulose conversion during enzymatic saccharification, and also had the highest abundance of 6-phospho-beta-glucosidase. However, combined $P$. acidilactici with the Acremonium cellulase exhibited better structural carbohydrates' degradation during the fermentation. Therefore, sole $P$. acidilactici treatment or in combination with Acremoniuum cellulase is a potential method that can enhance the utilization of $C$. korshinskii and reduce the waste of the lignocellulose resources, and subsequently serves as a biomass feedstock for biofuel production.

Page 11/20 


\section{Abbreviations}

$\mathrm{LAB}$

lactic acid bacteria

AC

Acremonium cellulase

CFU

colony-forming units

FW

fresh weight

$\mathrm{NH}_{3}-\mathrm{N}$

ammonia nitrogen

WSC

water-soluble carbohydrates

NPN

non-protein nitrogen

DM

dry matter

CP

crude protein

aNDF

neutral detergent fiber

ADF

acid detergent fiber

$A D L$

acid detergent lignin

SMRT

single molecule real-time sequencing technology

LEfSe

the linear discriminant analysis effect size

EC

enzyme classification.

\section{Declarations}

\section{Acknowledgements}

Not applicable.

\section{Authors' contributions}

$Y Z$ and JZ performed the experiment; $Y Z$ and $X G$ designed the experiment; $Y Z$ analyzed the data and wrote the first draft; MW, US, JB, $\mathrm{FL}$ and $X \mathrm{X}$ reviewed and edited the original manuscript. All authors approved the final manuscript for publication.

\section{Funding}

This study was supported by the National Natural Science Foundation of China (No. 31872417).

\section{Availability of data and materials}

We declare that all data generated or analyzed during this study are included in this published article.

\section{Ethics approval and consent to participate}

Not applicable. 


\section{Consent for publication}

Not applicable.

\section{Competing interests}

The authors declare that they have no competing interests.

\section{Author details}

${ }^{1}$ State Key Laboratory of Grassland Agro-ecosystems, School of Life Sciences, Lanzhou University, Lanzhou 730000, PR China. ${ }^{2}$ Probiotics and Biological Feed Research Centre, Lanzhou University, Lanzhou 730000, PR China. ${ }^{3}$ State Key Laboratory of Grassland Agro-ecosystems, College of Pastoral Agriculture Science and Technology, Lanzhou University, Lanzhou 730020, PR China.

\section{References}

1. Abraham A, Mathew AK, Park H, Choi O, Sindhu R, Parameswaran B, Pandey A, Park JH, Sang BI (2020) Pretreatment strategies for enhanced biogas production from lignocellulosic biomass. Bioresour Technol 301:122725. https://doi.org/10.1016/j.biortech.2019.122725

2. Alhaag H, Yuan XJ, Mala A, Bai JF, Shao T (2019) Fermentation characteristics of Lactobacillus plantarum and Pediococcus species isolated from sweet sorghum silage and their application as silage inoculants. Appl Sci 9:1247. https://doi.org/10.3390/app9061247

3. Alper H, Stephanopoulos G (2009) Engineering for biofuels: exploiting innate microbial capacity or importing biosynthetic potential? Nat Rev Microbiol 7:715-723. https://doi.org/10.1016/S0020-7519(03)00057-2

4. AOAC International 2005 Official Methods of Analysis of AOAC International. 16th ed Association of Analytical Chemists, Arlington, VA, USA.

5. Bai J, Ding ZT, Ke WC, Xu DM, Wang MS, Huang WK, Zhang YX, Liu F, Guo XS (2021) Different lactic acid bacteria and their combinations regulated the fermentation process of ensiled alfalfa: ensiling characteristics, dynamics of bacterial community and their functional shifts. Microb Biotechnol 14:1171-1182. https://doi.org/10.1111/1751-7915.13785

6. Birgen C, Degnes KF, Markussen S, Wentzel A, Sletta H (2021) Butanol production from lignocellulosic sugars by Clostridium beijerinckii in microbioreactors. Biotechnol Biofuels 14:1-12. https://doi.org/10.1186/s13068-021-01886-1

7. Chen L, Gu W, Xu HY, Yang GL, Shan XF, Chen G, Kang YH, Wang CF, Qian AD (2018) Comparative genome analysis of Bacillus velezensis reveals a potential for degrading lignocellulosic biomass. 3 Biotech 8:1-5. https://doi.org/10.1007/s13205-018-1270-7

8. Dehghani MR, Weisbjerg MR, Hvelplund T, Kristensen NB (2012) Effect of enzyme addition to forage at ensiling on silage chemical composition and NDF degradation characteristics. Livest Sci 150:51-58. https://doi.org/10.1016/j.livsci.2012.07.031

9. Desta ST, Yuan XJ, Li JF, Shao T (2016) Ensiling characteristics, structural and nonstructural carbohydrate composition and enzymatic digestibility of Napier grass ensiled with additives. Bioresour Technol 221:447-454.

https://doi.org/10.1016/j.biortech.2016.09.068

10. Ding ZT, Xu DM, Bai J, Li FH, Adesogan AT, Zhang P, Yuan XJ, Guo XS (2019) Characterization and identification of ferulic acid esterase-producing Lactobacillus species isolated from Elymus nutans silage and their application in ensiled alfalfa. J Appl Microbiol 127:985-995. https://doi.org/10.1111/jam.14374

11. Dong Z, Shao T, Li J, Yang L, Yuan X (2020) Effect of alfalfa microbiota on fermentation quality and bacterial community succession in fresh or sterile Napier grass silages. J Dairy Sci 103:4288-4301. https://doi.org/10.3168/jds.2019-16961

12. Fujii T, Fang X, Inoue H, Murakami K, Sawayama S (2009) Enzymatic hydrolyzing performance of Acremonium cellulolyticus and Trichoderma reesei against three lignocellulosic materials. Biotechnol Biofuels 2:24-31. https://doi.org/10.1186/1754-6834-2-24

13. Hu F, Ragauskas A (2012) Pretreatment and lignocellulosic chemistry. Bioenerg Res 5:1043-1066. https://doi.org/10.1007/s12155-012-9208-0

14. Jurado M, Prieto A, Martínez-Alcalá Á, Martínez ÁT, Martínez MJ (2009) Laccase detoxification of steam-exploded wheat straw for second generation bioethanol. Bioresour Technol 100:6378-6384. https://doi.org/10.1016/j.biortech.2009.07.049

15. Ke WC, Ding WR, Xu DM, Ding LM, Zhang P, Li FD, Guo XS (2017) Effects of addition of malic or citric acids on fermentation quality and chemical characteristics of alfalfa silage. J Dairy Sci 100:8958-8966. https://doi.org/10.3168/jds.2017-12875 
16. Khota W, Pholsen S, Higgs D, Cai Y (2016) Natural lactic acid bacteria population of tropical grasses and their fermentation factor analysis of silage prepared with cellulase and inoculant. J Dairy Sci 99:9768-9781. https://doi.org/10.3168/jds.2016-11180

17. Kilstrup M, Hammer K, Jensen PR, Martinussen J (2005) Nucleotide metabolism and its control in lactic acid bacteria. FEMS Microbiol Rev 29:555-590. https://doi.org/10.1016/j.fmrre.2005.04.006

18. Kung Jr L (2008) Silage fermentation end products and microbial populations: their relationships to silage quality and animal productivity. In: Annual Conference of the American Association of Bovine Practitioners, Sept 25-27, Charlotte, NC.

19. Li FH, Ding ZT, Ke WC, Xu DM, Zhang P, Bai J, Mudassar S, Muhammad I, Guo X (2019) Ferulic acid esterase-producing lactic acid bacteria and cellulase pretreatments of corn stalk silage at two different temperatures: Ensiling characteristics, carbohydrates composition and enzymatic saccharification. Bioresour Technol 282:211-221. https://doi.org/10.1016/j.biortech.2019.03.022

20. Li FH, Ke WC, Ding ZT, Bai J, Zhang YX, Xu DM, Li ZQ, Guo XS (2020) Pretreatment of Pennisetum sinese silages with ferulic acid esterase-producing lactic acid bacteria and cellulase at two dry matter contents: Fermentation characteristics, carbohydrates composition and enzymatic saccharification. Bioresour Technol 295:122261. https://doi.org/10.1016/j.biortech.2019.122261

21. Li J, Yuan X, Dong Z, Mugabe W, Shao T (2018) The effects of fibrolytic enzymes, cellulolytic fungi and bacteria on the fermentation characteristics, structural carbohydrates degradation, and enzymatic conversion yields of Pennisetum sinese silage. Bioresour Technol 264:123-130. https://doi.org/10.1016/j.biortech.2018.05.059

22. Li P, Zhang Y, Gou WL, Cheng QM, Bai SQ, Cai YM (2019) Silage fermentation and bacterial community of bur clover, annual ryegrass and their mixtures prepared with microbial inoculant and chemical additive. Anim Feed Sci Tech 247:285-293. https://doi.org/10.1016/j.anifeedsci.2018.11.009

23. Li WC, Han LJ, Peng TB, Xie YY, Zou Y, Li LZ, Jia SR, Zhong C (2020) Structural and behavior changes of herbaceous and hardwood biomass during steam explosion pretreatment and enzymatic hydrolysis. Bioresour Technol 15:691-705. https://doi.org/10.15376/biores.15.1.691-705

24. Li WC, Zhang SJ, Zhang TZ, Shen YQ, Han LJ, Peng ZJ, Xie ZX, Zhong C, Jia S (2021) Bacterial cellulose production from ethylenediamine pretreated Caragana korshinskii Kom. Ind Crop Prod 164:113340. https://doi.org/10.1016/j.indcrop.2021.113340

25. Licitra G, Hernandez TM, Van Soest PJ (1996) Standardization of procedures for nitrogen fractionation of ruminant feeds. Anim Feed Sci Tech 57:347-358. https://doi.org/10.1016/0377-8401(95)00837-3

26. Liu Q, Li J, Zhao J, Wu J, Shao T (2019) Enhancement of lignocellulosic degradation in high-moisture alfalfa via anaerobic bioprocess of engineered Lactococcus lactis with the function of secreting cellulase. Biotechnol Biofuels 12:1-17. https://doi.org/10.1186/s13068-019-1429-4

27. Liu Q, Zhang Y, Zhang Y, Xu X, Zhang W, Liu B, Gu Q (2014) Heterologous expression, purification and characterization of thermostable 6-phosphate- $\beta$-glucosidase TteBglB. J Agr Sci and Tech-Iran 16:52-58.

28. Méndez-García C, Pelaez Al, Mesa V, Sanchez J, Golyshina OV, Ferrer M (2015) Microbial diversity and metabolic networks in acid mine drainage habitats. Front Microbiol 6:475. https://doi.org/10.3389/fmicb.2015.00475

29. Nolan JV, Hegarty RS, Hegarty J, Godwin IR, Woodgate R (2010) Effects of dietary nitrate on fermentation, methane production and digesta kinetics in sheep. Anim Prod Sci 50:801-806. https://doi.org/10.1071/AN09211

30. Oladosu Y, Rafii MY, Abdullah N, Magaji U, Hussin G, Ramli A, Miah G (2016) Fermentation quality and additives: a case of rice straw silage. Biomed Res Int 2016:1-14. https://doi.org/10.1155/2016/7985167

31. Pérez J, Munoz-Dorado J, De la Rubia TDLR, Martinez J (2002) Biodegradation and biological treatments of cellulose, hemicellulose and lignin: an overview. Int Microbiol 5:53-63. https://doi.org/10.1007/s10123-002-0062-3

32. Phitsuwan P, Sakka K, Ratanakhanokchai K (2016) Structural changes and enzymatic response of Napier grass (Pennisetum purpureum) stem induced by alkaline pretreatment. Bioresour Technol 218:247-256. https://doi.org/10.1016/j.biortech.2016.06.089

33. Porto MCW, Kuniyoshi TM, Azevedo POS, Vitolo M, Oliveira RS (2017) Pediococcus spp.: An important genus of lactic acid bacteria and pediocin producers. Biotechnol Adv 35:361-374. https://doi.org/10.1016/j.biotechadv.2017.03.004.

34. Ranjan A, Moholkar VS (2012) Biobutanol: science, engineering, and economics. Int J Energ Res 36:277-323. https://doi.org/10.1002/er.1948

35. Resch MG, Baker JO, Decker SR (2015) Low Solids Enzymatic Saccharification of Lignocellulosic Biomass. Golden, CO: National Renewable Energy Laboratory. 
36. Shinozaki Y, Kitamoto HK (2011) Ethanol production from ensiled rice straw and whole-crop silage by the simultaneous enzymatic saccharification and fermentation process. J Biosci Bioeng 111:320-325. https://doi.org/10.1016/j.jbiosc.2010.11.003

37. Thomas TA (1977) An automated procedure for the determination of soluble carbohydrates in herbage. J Sci Food Agr 28:639642. https://doi.org/10.1002/jsfa.2740280711

38. Xu D, Wang N, Rinne M, Ke W, Weinberg ZG, Da M, Bai J, Zhang Y, Li F, Guo X (2020) The bacterial community and metabolome dynamics and their interactions modulate fermentation process of whole crop corn silage prepared with or without inoculants. Microb Biotechnol 14:561-576. https://doi.org/10.1111/1751-7915.13623

39. Xu F, Sun RC, Lu Q (2006) Characteristics of cellulose isolated by a totally chlorine-free method from Caragana korshinskii. J Appl Polym sci 101:3251-3263. https://doi.org/10.1002/app.23667

40. Xu XC, Ma L, Fan SS, Ma WP, Zhang X (2020) Effects of fermented caragana korshinskii feed on meat quality characteristics in different muscles of Tan sheep. Ital J Anim Sci 19:1036-1045. https://doi.org/10.1080/1828051X.2020.1816505

41. Yang L, Yuan X, Li J, Dong Z, Shao T (2019) Dynamics of microbial community and fermentation quality during ensiling of sterile and nonsterile alfalfa with or without Lactobacillus plantarum inoculant. Bioresour Technol 275:280-287. https://doi.org/10.1016/j.biortech.2018.12.067

42. Zhang GJ, Li Y, Fu YR, Lu C, Hu JY (2009) Silage quality of Robinia pseudoacacia, Caragana korshinskii and Amorpha fruticosa. J Northwest Forestry University 24:151-156

43. Zhang YX, Ke WC, Bai J, Li FH, Xu DM, Ding ZT, Guo XS (2020) The effect of Pediococcus acidilactici J17 with high-antioxidant activity on antioxidant, $\alpha$-tocopherol, $\beta$-carotene, fatty acids, and fermentation profiles of alfalfa silage ensiled at two different dry matter contents. Anim Feed Sci Tech 268:114614. https://doi.org/10.1016/j.anifeedsci.2020.114614

44. Zhang YX, Ke WC, Vyas D, Adesogan AT, Franco M, Li FH, Bai J, Guo XS (2021) Antioxidant status, chemical composition and fermentation profile of alfalfa silage ensiled at two dry matter contents with a novel Lactobacillus plantarum strain with highantioxidant activity. Anim Feed Sci Tech 272:114751. https://doi.org/10.1016/j.anifeedsci.2020.114751

45. Zhao S, Yao S, Ou S, Lin J, Wang Y, Peng X, Li A, Yu B (2014) Preparation of ferulic acid from corn bran: Its improved extraction and purification by membrane separation. Food Bioprod Process 92:309-313. https://doi.org/10.1016/j.fbp.2013.09.004

46. Zheng ML, Niu DZ, Jiang D, Zuo SS, Xu CC (2017) Dynamics of microbial community during ensiling direct-cut alfalfa with and without LAB inoculant and sugar. J Appl Microbiol 122:1456-1470. https://doi.org/10.1111/jam.13456

47. Zhou ZY, Yu MH, Ding GD, Gao GL, He YY (2020) Diversity and structural differences of bacterial microbial communities in rhizocompartments of desert leguminous plants. PloS one 15:e0241057. https://doi.org/10.1371/journal.pone.0241057

\section{Figures}



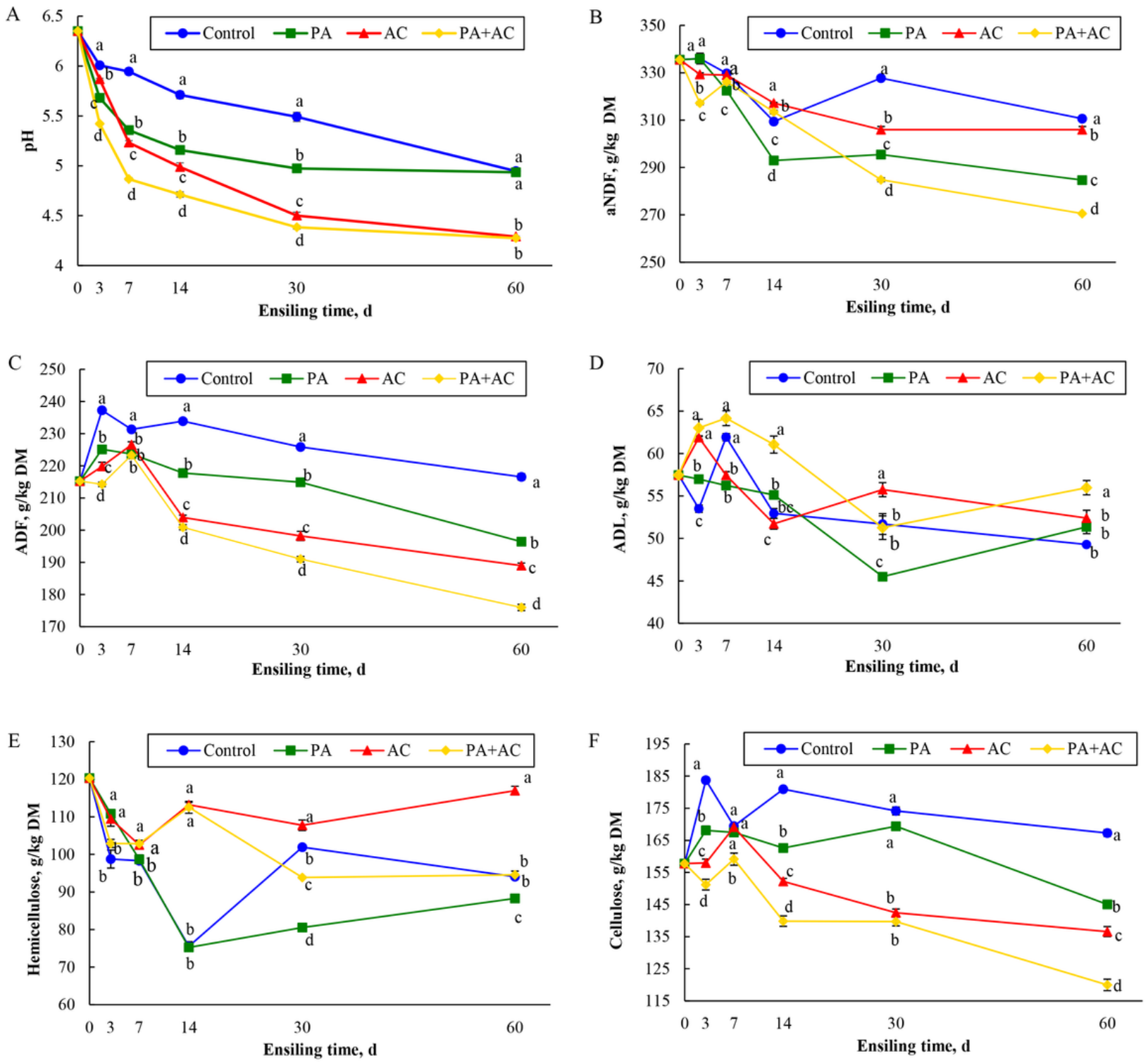

\section{Figure 1}

Dynamics of $\mathrm{pH}(\mathrm{A})$ and structural carbohydrates (B, aNDF; C, ADF; D, ADL; E, hemicellulose; F, cellulose) of ensiled C. korshinskii as influenced by additives and ensiling period. Treatment: Control, without additive; PA, P. acidilactici; AC, Acremonium cellulase; PA+AC, a cobinaiton of $P$. acidilactici and Acremonium cellulase; aNDF, neutral detergent fiber assayed with a heat-stable amylase and expressed inclusive of residual ash; ADF, acid detergent fiber; $A D L$, acid detergent lignin. Means with different lowercases (a-d) among treatments at the same time point differed $(P<0.05 ; n=4$, bars indicate standard error of means). The effects of ensiling time, additives, and their interaction had a $P$-value of $<0.05$. 


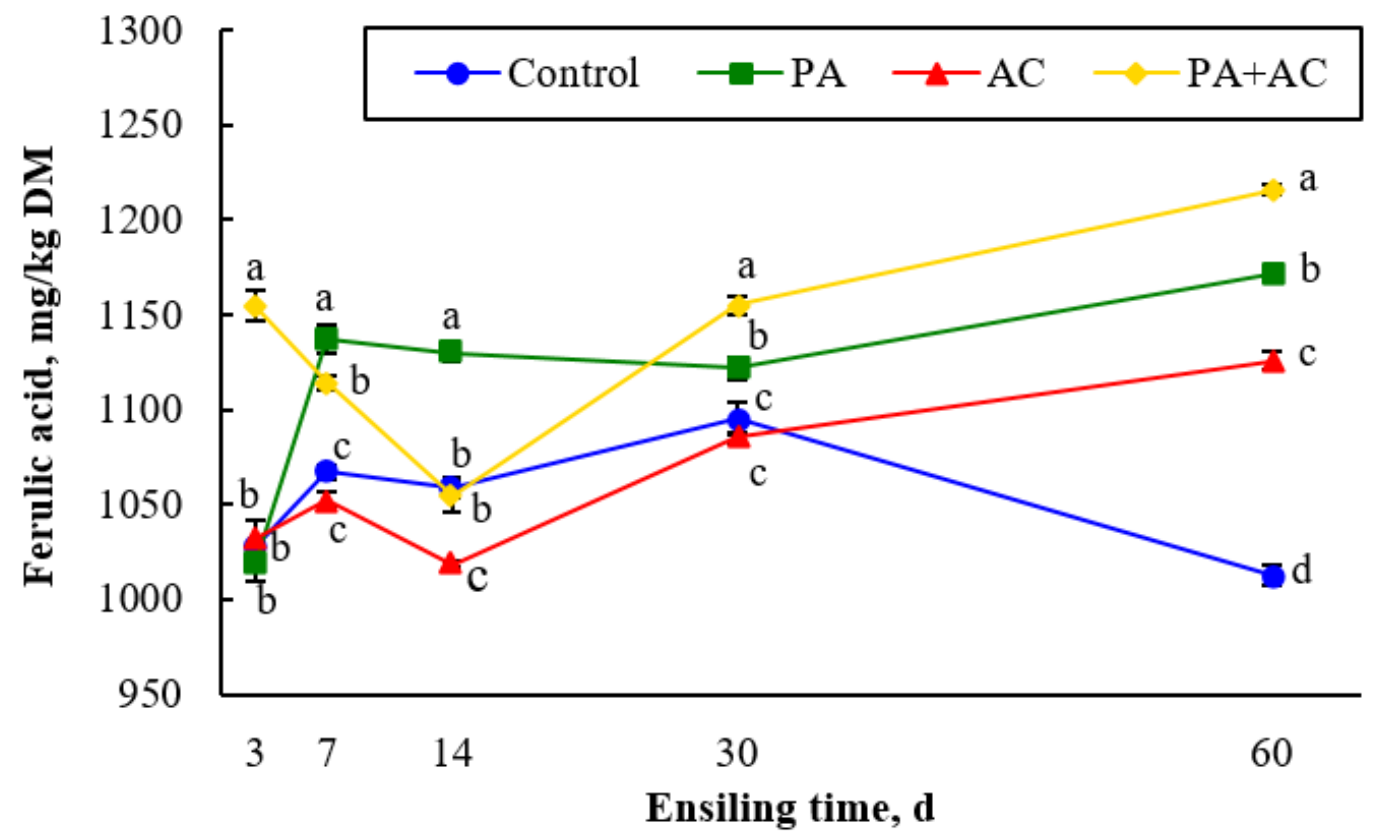

Figure 2

Ferulic acid concentrations of ensiled $C$. korshinskii as influenced by additives and ensiling period. Treatment: Control, without additive; PA, P. acidilactici; AC, Acremonium cellulase; PA+AC, a combination of $P$. acidilactici and Acremonium cellulase. Means with different lowercases $(a-d)$ among treatments at the same time point differed $(P<0.05 ; n=4$, bars indicate standard error of means). The effects of ensiling time, additives, and their interaction had a $P$-value of $<0.05$. 
C

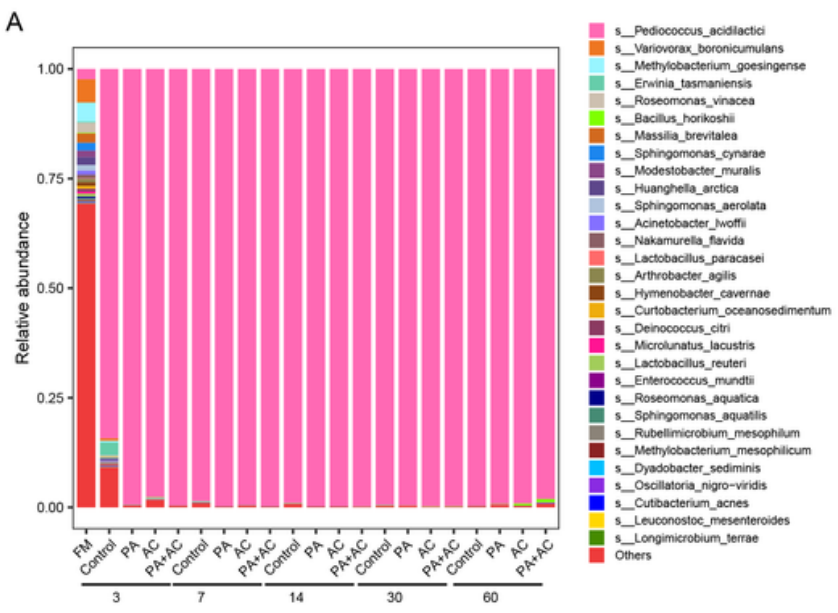

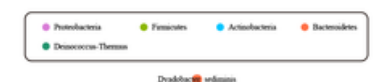

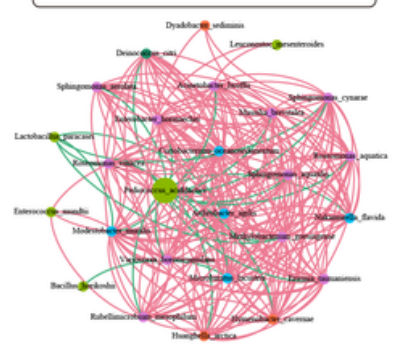

Control

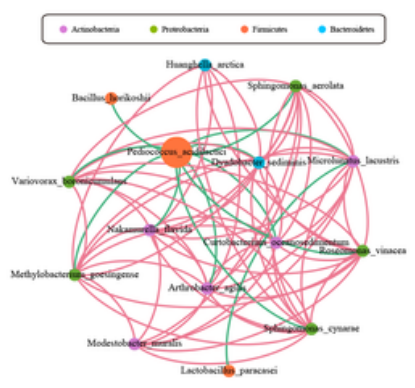

$\mathrm{AC}$

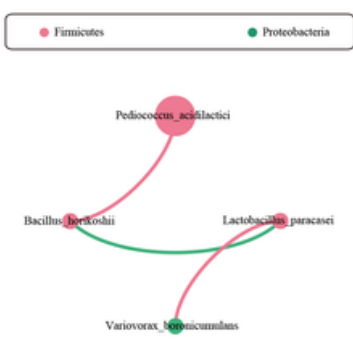

PA

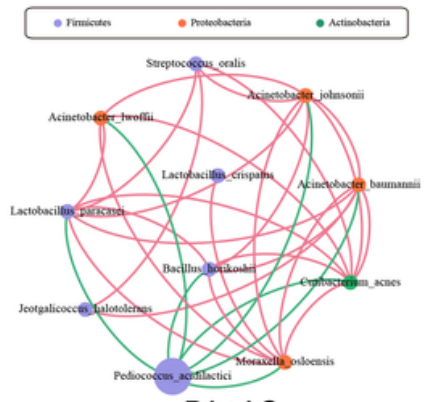

$P A+A C$
B a

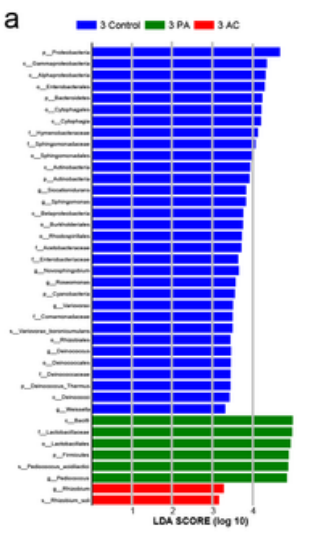

b

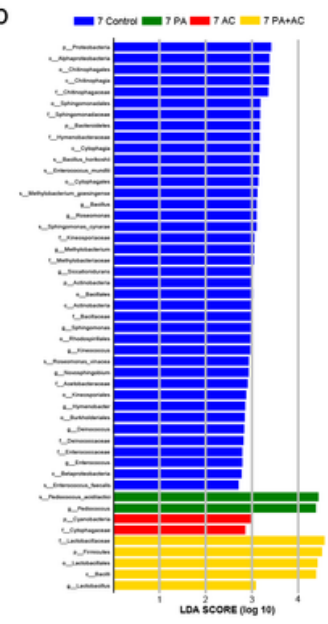

C

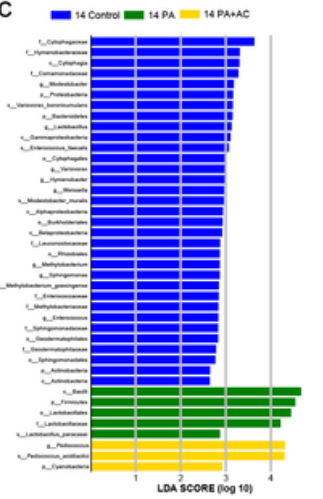

d

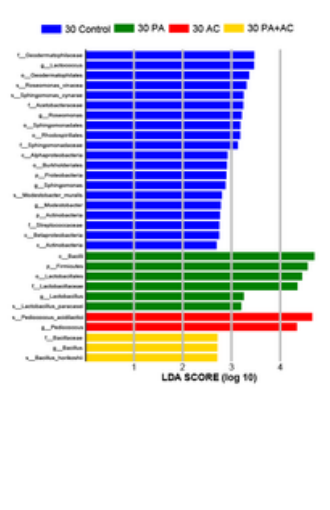

e

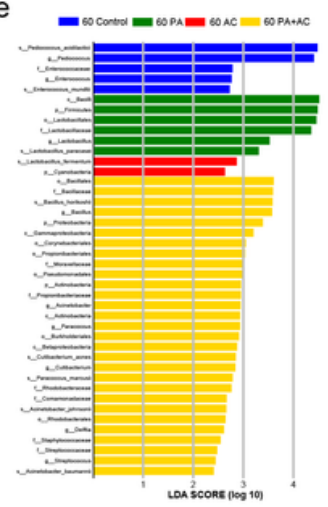

Figure 3

Bacterial community composition, differences and interactional neworks of ensiled $C$. korshinskii. Treatment: control, without additive; PA, P. acidilactici; AC, Acremonium cellulase; PA+AC, a combination of $P$. acidilactici and Acremonium cellulase. Arabic number indicating days of ensiling.

A. Comparison of microbiota compositions at species level of fresh and ensiled $C$. korshinskii as influenced by additives and ensiling period.

B. Comparison of the communities or species that have significant differences among different additive treatments and ensiling time using the LEfSe analysis.

C. Comparison of interaction networks of the $C$. korshinskii silage microbiota. Node size is scaled based on the overall abundance of each taxon in the microbiota. Edge width is proportional to the strength of association between each metabolite-phylotype pair (as measured by the correlation), red edge indicates positive correlations and green edge indicates negative corrections. 
A

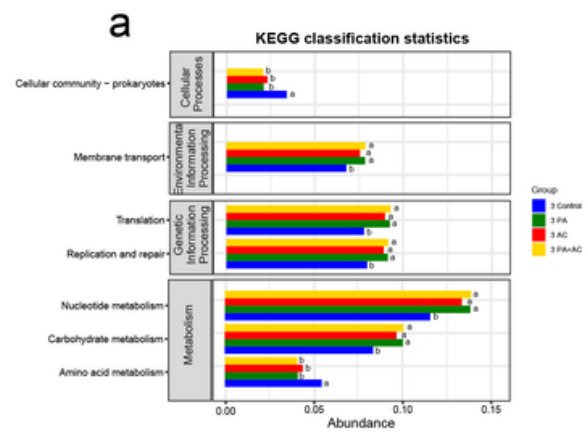

d

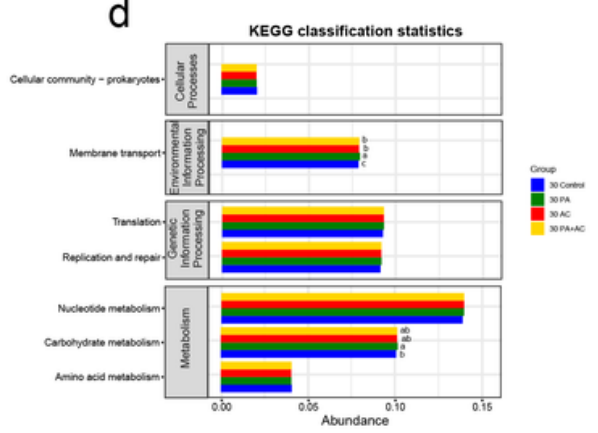

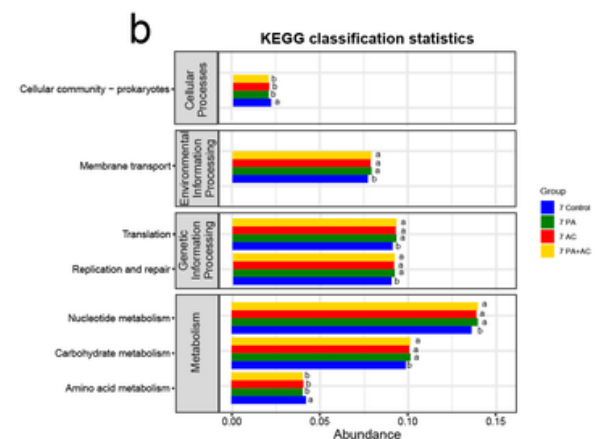

e

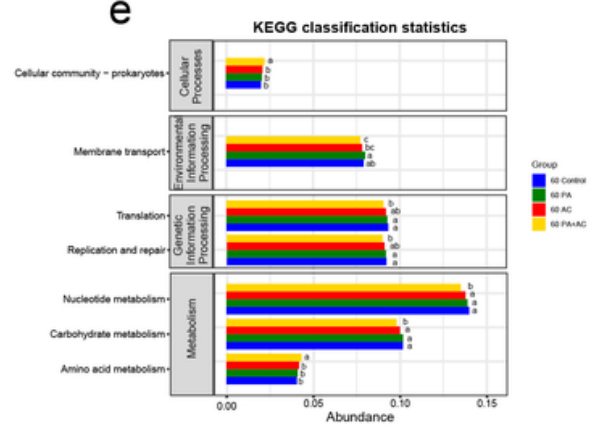

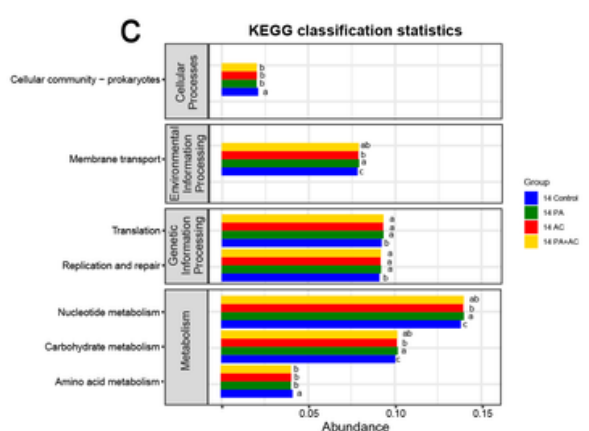

B

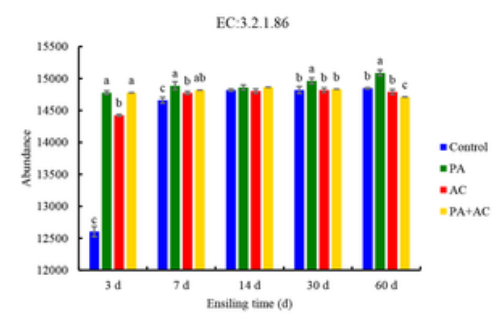

\section{Figure 4}

Functional prediction of bacterial changes in C. korshinskii after fermentation using Phylogenetic Investigation of Communities by Reconstruction of Unobserved States (PICRUSt2). Treatment: control, without additive; PA, P. acidilactici; AC, Acremonium cellulase; PA+AC, a combination of $P$. acidilactici and Acremonium cellulase.

A. Level 2 KEGG orthologue gene of ensiled $C$. korshinskii as influenced by additives and ensiling period. Arabic number indicating days of ensiling.

B. The abundance of 6-phospho-beta-glucosidase (EC:3.2.1.86) of ensiled C. korshinskii as influenced by additives and ensiling period. 

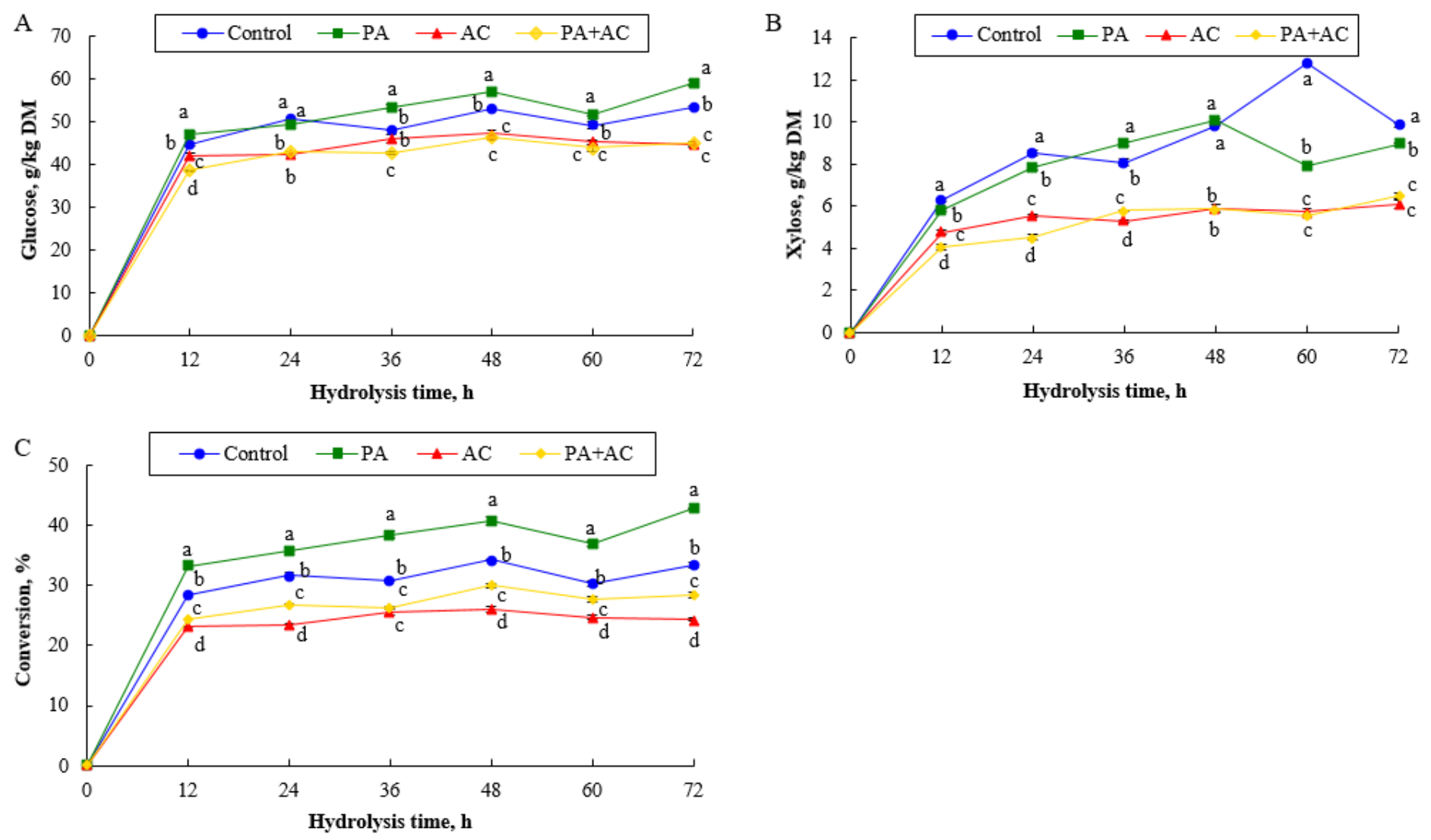

Figure 5

Sugar yield (A, glucose; $B$, xylose) and cellulose conversion (C) of ensiled $C$. korshinskii as influenced by additives and hydrolysis time. Treatment: Control, without additive; PA, P. acidilactici; AC, Acremonium cellulase; PA+AC, a combination of $P$. acidilactici and Acremonium cellulase. Means with different lowercases $(a-d)$ among treatments at the same time point differed $(P<0.05 ; n=4$, bars indicate standard error of means). The effects of hydrolysis time, additives, and their interaction had a $P$-value of $<0.05$.

\section{Supplementary Files}

This is a list of supplementary files associated with this preprint. Click to download.

- Graphicabstract.pdf 